\title{
Towards the future: The final issue of the journal of the Royal Army Medical Corps 1903-2019
}

Every successful scientific and medical journal needs to adapt to its circumstances: its place in time, in the scientific order of things and its place in the society that it serves. In the 116 years of continuous print publication since its introduction in 1903, the Journal of The Royal Army Medical Corps (JRAMC) has adapted with great success. Some of the highlights are described in two specific articles published in this final issue of the journal. ${ }^{12}$ In its early days it combined the function of a regimental magazine with some mainly personal views on clinical medicine. It listed news of RAMC units around the globe allowing officers to keep track of one another and of wider Corps news.

The First World War saw a rapid expansion in medical science as the Corps came to terms with the necessary advances in health, hygiene, evacuation, war surgery and infectious disease. In many cases the advances were introduced by the RAMC and the journal contains a vital archive of original work from this era. Examples include the first description of 'Shell Shock', now commonly referred to as Post Traumatic Stress Disorder and articles on improvements in the surgical care of war wounds. Regimental news migrated to a separate RAMC magazine, now titled The Medic. This successfully continues the role of updating the readership on Unit and wider Corps news. Meanwhile JRAMC continued to evolve as a scientific medical journal with the introduction of a general conformity in standards of medical publishing, independent peer review, and agreement on a nomenclature system for references and other changes.

In 2013 production was moved from in-house to BMJ, although it was still wholly owned by the RAMC Charity. Not only did this provide the JRAMC with access to their formidable publishing network, it enabled articles to be published 'online first' within weeks of

${ }^{1}$ Royal Centre for Defence Medicine, Birmingham B15 2SQ, UK

${ }^{2}$ Department of Maxillofacial Surgery, University Hospitals Birmingham, Birmingham B15 2TH, UK

Correspondence to Lieutenant Colonel Johno Breeze, Royal Centre for Defence Medicine, Birmingham B15 2SQ, UK; editor.jramc@bmj.com acceptance. BMJ promoted in particular, the use of social media in promulgating the messages found in JRAMC articles, but learned that as a journal run by and authored by serving military officers, that would have its own challenges! Finally, the achievement of an Impact Factor, despite all the flaws in such a metric, has enabled the journal to be rated on an international platform. In 2019 the JRAMC achieved an IF of 0.994 and became the most highly cited and downloaded military medical journal in the world.

The title Royal Army Medical Corps and the regimental crest that appear throughout this journal and elsewhere reflect two meanings and joint ownership. The RAMC is a Sovereign Corps of the British Army and the crest is the regimental cap badge, both clearly within the ownership of the United Kingdom's Ministry of Defence. However, they are also the title and crest of the RAMC Charity, a registered charity that is run by trustees and by the Regimental Headquarters and paid for by voluntary donations from members of the Corps and by the income from its endowments. Until 2009, JRAMC was owned by a separate charity, but in that year, all the constituent charities of the Corps were merged into a single RAMC charity. The Articles of Association of the converged single charity conform to the requirements and expectations of the Charity Commission with the broad aims of bringing benefit to the serving members of the RAMC and thereby improving military morale and efficiency. Within this framework, the Journal was an uncomfortable bed-fellow. The benefit was really only for officers and mainly for medical officers. The position was defended by noting that soldiers gained indirectly from a general enhancement of the status of the RAMC brought about by the journal's reputation.

This duality of the title causes confusion to the wider readership, to many within the Ministry of Defence (MoD), and not infrequently to members of the Corps. It is the charity that owns the journal. Many authors and readers have incorrectly assumed that the Journal will reflect the views of the UK MoD. All UK service personnel must have permission to publish - on any subject and in any format, written electronic or at interview. This is a necessary requirement to preserve security and to ensure that the views of the MoD are not falsely represented. However, the Trustees of the RAMC Charity have always seen editorial independence as a requirement for the journal to retain the credibility it had strived so hard to establish and have on occasions been required to defend it.

Following the association of the Journal with BMJ, it has become increasingly a publication not just for the RAMC and wider UK Defence Medical Services but for an international readership and authorship. This takes it outside the original aims of the RAMC Charity and led the Trustees to conclude that the Journal could no longer achieve its full potential and should cease publication if a successor publication could provide all the benefits. The RAMC charity approached the BMJ and in September 2019 an agreement was made between the institutions. JRAMC would cease publication and BMJ would publish a new international journal of military health. That journal will acknowledge fully its heritage from JRAMC, it will continue to foster a close relationship with the RAMC and other parts of the UK Defence Medical Services, but at the same time develop further the international flavour.

As Editor in Chief I am indebted to many who have gone before me, for which I will write separately in the first issue of the successor to JRAMC. During my biannual visits to Robertson House to report to the trustees of the charity I realised how difficult a task they perform in such a role. It was however clear that their primary focus was ever to represent the best interests of authors and readers. I would like to specifically highlight the role of Brigadier Peter Fabricius, who has been instrumental in this final transition of the journal. $\mathrm{He}$ has demonstrated real vision in recognising that this change to the journal had to occur, and engaged early with the BMJ to ensure that a successor journal would be formed that could continue to champion global advances in military health for future generations. Many of the words used in this final editorial are those of 
Brigadier Fabricius, and I know that as JRAMC closes, he and the other Trustees of the RAMC charity wish every success to its successor.

In Arduis Fidelis

Funding The authors have not declared a specific grant for this research from any funding agency in the public, commercial or not-for-profit sectors.
Patient consent for publication Not required.

Provenance and peer review Commissioned; internally peer reviewed

(C) Author(s) (or their employer(s)) 2019. No commercial re-use. See rights and permissions. Published by BMJ.

To cite Breeze J. J R Army Med Corps 2019;165:381-382.

J R Army Med Corps 2019;165:381-382. doi:10.1136/jramc-2019-001372

\section{REFERENCES}

1 Macmillan A. Tribute to the Journal of the RAMC. J Royal Army Med Corps 2019;6:382-6.

2 Barker T. Interests and concerns of the Army Medical Services as reflected by the publications in the Journal of the Royal Army Medical Corps 1903-2019. J R Army Med Corps 2019;6:425-34. 